\title{
9 MJ LABORATORY GUN AND RANGE AT THE UNIVERSITY OF TEXAS AT AUSTIN
}

R. C. Zowarka, Jr., D. R. Peterson, J. H. Price, and W. F. Weldon

\author{
Presented at the \\ 4th Symposium on Electromagnetic \\ Launch Technology \\ Austin, Texas \\ Apri1 12-14, 1988
}

Publication No. PR-78 Center for Electromechanics The University of Texas at Austin Balcones Research Center EME 1.100, Building 133

Austin, TX 78758-4497 (512) $471-4496$ 
Abstract: The joint DARPA/Army electromagnetic (EM) technology demonstration program was established in response to a 1985 Defense Science Board study on armor/antiarmor. The board identified deficiencies in armor/antiarmor capabilities and suggested that they be rectified as quick1y as possible. In response to this need the Defense Advanced Research Projects Agency (DARPA) initiated a high risk high payof $f$ program that included integrated advanced development and proof-of-principle demonstrations in major related technologies. Within this broader structure the EM gun technology demonstration program was initiated. To accomplish the overall goals the program was structured into several mission specific Tasks involving the design and operation of a single shot EM gun with 9 MJ muzzle energy and demonstrated velocities in the 2.5 to $4 \mathrm{~km} / \mathrm{s}$ regime, a repetitive EM gun system 9 MJ muzzle energy, and pursuit of the design of advanced projectiles.

This paper describes the 9 MJ 1aboratory gun and range initiative at The University of Texas at Austin. The goal of the program is to demonstrate a single shot EM gun suitable for establishing gun parameters for the repetitive EM gun systems and for supporting profectile development. Phase I of this program has been completed wherein the power supply has been prepared, the range has been designed and constructed, a one half scale and a full scale gun have been designed and constructed, and the one half scale gun has been assembled and undergone initial tests. Of significance is that this part of the program was accomplished in one year, a fast paced schedule indeed. Also of significance is that within a six shot test sequence on the one half scale gun the electric gun has matched the muzzle velocity of the conventional gun that is operated on the MlEl battle tank.

\section{Power Supply Preparation}

The Balcones Hypervelocity EM Gun Test Facility is shown in figure 1. Below ground in an hexagonal pit are the six, $10 \mathrm{MJ}$, drum-type homopolar generators (HPGs). The power conditioning of the output of the HPGs is done with two turn room temperature copper coaxial inductors. The $6.2 \mathrm{H}$ inductors store $4.5 \mathrm{MJ}$ of inductive energy at the HPGs peak discharge current of $1.2 \mathrm{MA}$. The inductance energy is commutated to the load with single stage explosive opening switches. A11 switch contro1 functions and firing circuits are fiber optically isolated for noise immunity and a high degrees of electrical isolation. The six power supply outputs collect in a common coaxial bus at the center of the hex-pit. The total discharge current is delivered to the railgun load via a ten plate laminated bus designed with low inductance to have manageable magnetic pressure at high current operation. [1]

The circuit schematic for the system is shown in figure 2. Different levels of output energy are produced by varying the generator speed and varying levels of output current are provided by staging the

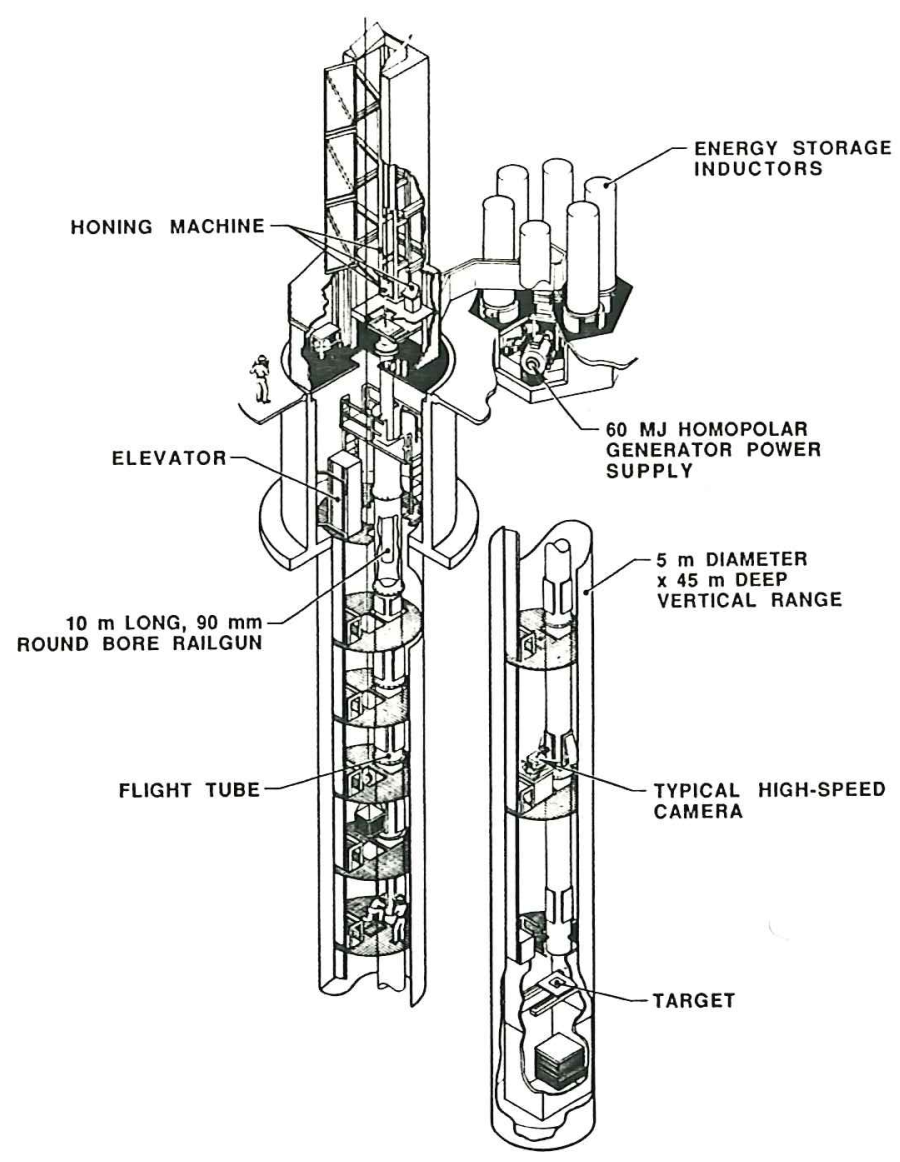

Figure 1. Vertical range

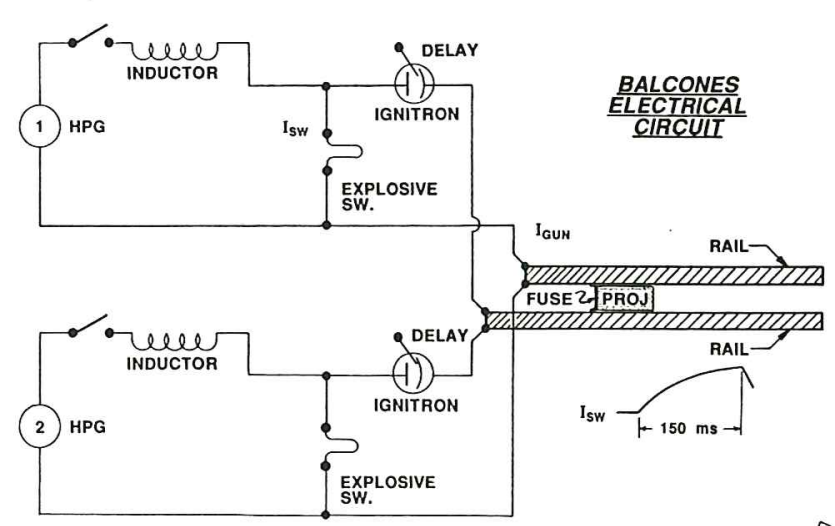

(3)

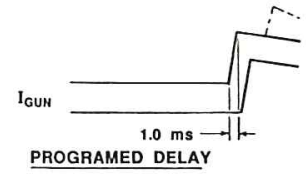

Figure 2. Circuit diagram 


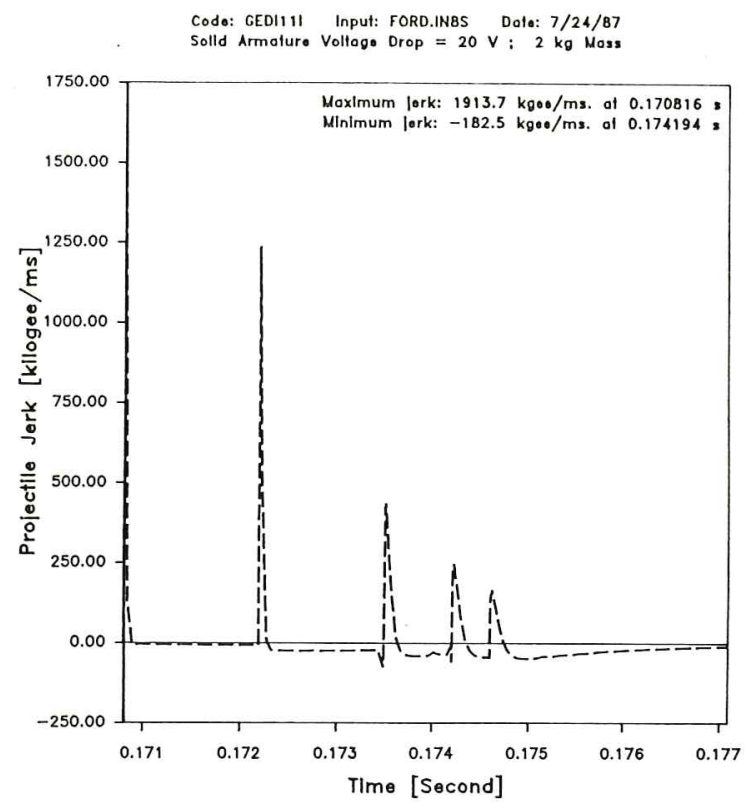

Figure 6. Tactical railgun computer mode1 (projectile jerk vs. time)

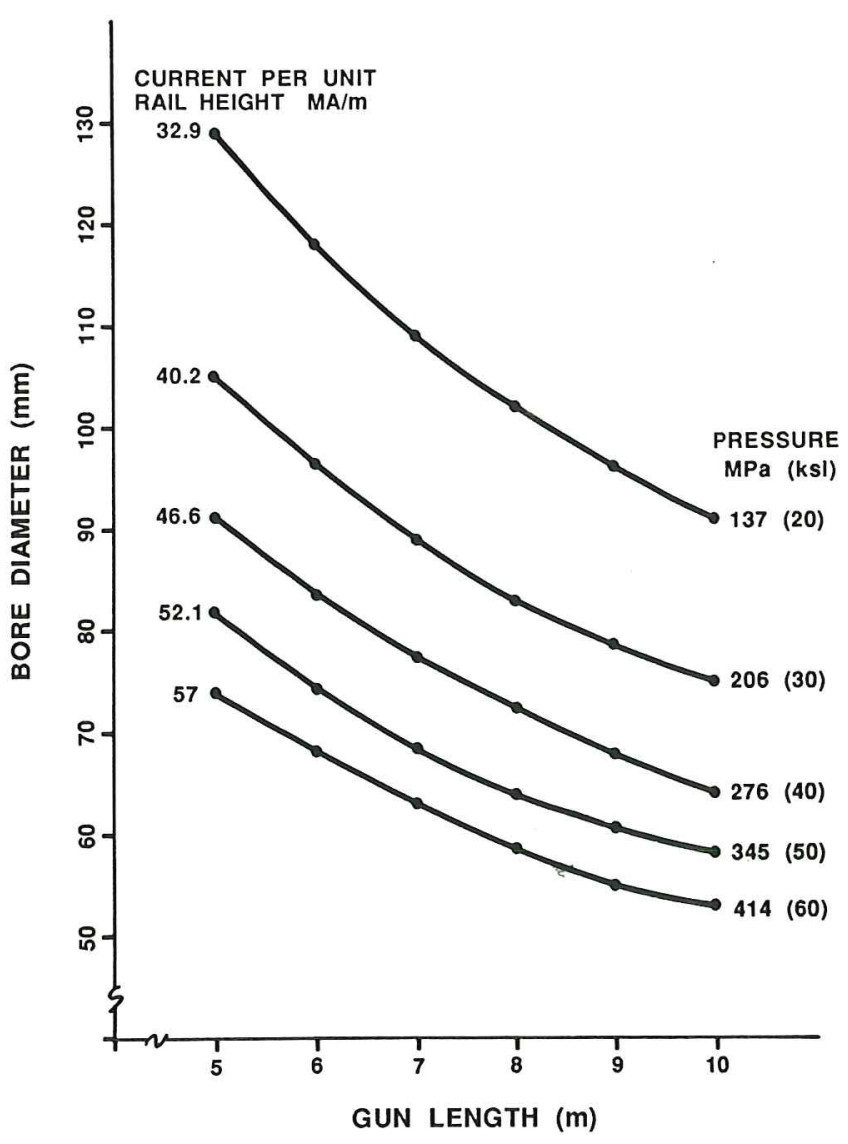

Figure 7. 9 MJ muzzle energy (constant pressure) selected to be round. A simple yet representative projectile design may also be analyzed to bracket railgun design parameters. Figure 8 depicts a simplified segmented rod penetrator. The sabot material was selected to have a density of $1,500 \mathrm{~kg} / \mathrm{m}^{3}$ and the penetrator segments were selected as tungsten with a density of $17,000 \mathrm{~kg} / \mathrm{m}^{3}$ and an $\mathrm{L} / \mathrm{D}=1$. A constant solid armature mass of $500 \mathrm{~g}$ is selected for a11 designs. Figures 9 and 10 show the acceleration surfaces above the bore diameter gun length plane. It can be seen that moving to larger bores lowers the acceleration and projectile stress but at the same time decreases the kinetic energy in the penetrator thus lowering the efficiency.

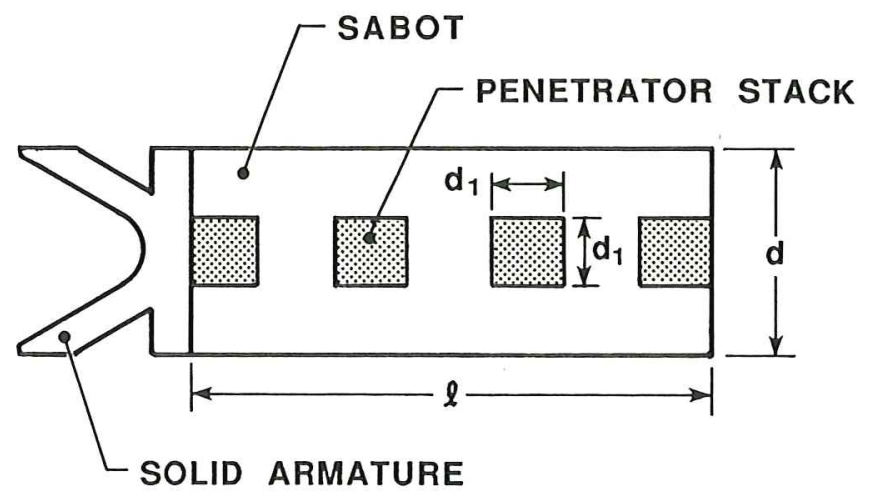

$\mathrm{d}_{1}=15 \mathrm{~mm}$

SOLID ARMATURE MASS $=500 \mathrm{~g}$

Figure 8. Baseline projectile

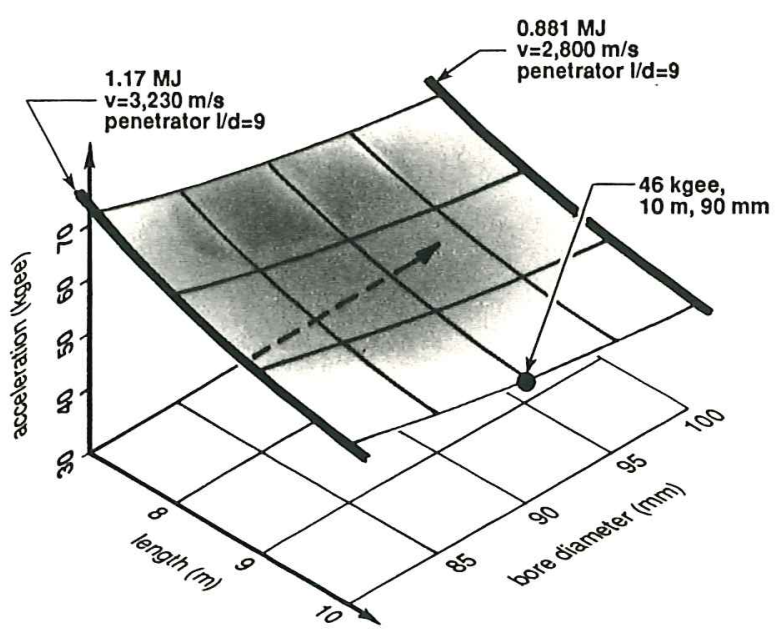

Figure 9. Acceleration vs. bore diameter and gun length

The region centered about $90 \mathrm{~mm}$ bore diameter and $10 \mathrm{~m}$ gun length once again represented a viable design as these tradeoffs were considered.

With the gun parameters selected studies were undertaken to identify materials and construction methods. The design goals were enhanced structural stiftness, little compromise of electrical performance due to conducting support structures close to the 
discharge of the generators. In operation all HPGs are motored to the same speed. Before discharge begins the field excitation is turned on and at the peak field level the brushes are dropped to start the discharge. The discharge achieves a relatively flat 10 to $20 \mathrm{~ms}$ long current peak in approximately $150 \mathrm{~ms}$. It is within this flat top region that experiments are conducted. A timer times out at peak current and the first opening switch is fired. The voltage produced by the switch passively triggers the ignitron thus establishing a current path into the railgun. In addition an active trigger from the controller is provided to the ignitron to insure conduction. Current then commutates into the 1auncher. It cannot commutate into any of the remaining low conductivity state opening switches because they are blocked from the load with their own individual ignitrons. At a preset time delay the second opening switch fires and the next increment of current commutates into the 1oad. It cannot commutate into the first pulsed power circuit because the impedance of the inductor is too large and it cannot share with other opening switches because they are protected by an off-state ignitron. In this manner different time varying current waveforms may be generated providing a very versatile power supply Simulation codes were executed to establish system operating parameters which would provide the required Task B performance of $2 \mathrm{~kg}$ to 3 $\mathrm{km} / \mathrm{s}, 9 \mathrm{MJ}$ muzzle energy[2]. Figures 3 to 6 give the current, velocity, acceleration, and jerk vs. time using representative parameters in the Balcones Hypervelocity Test Facility system simulation.

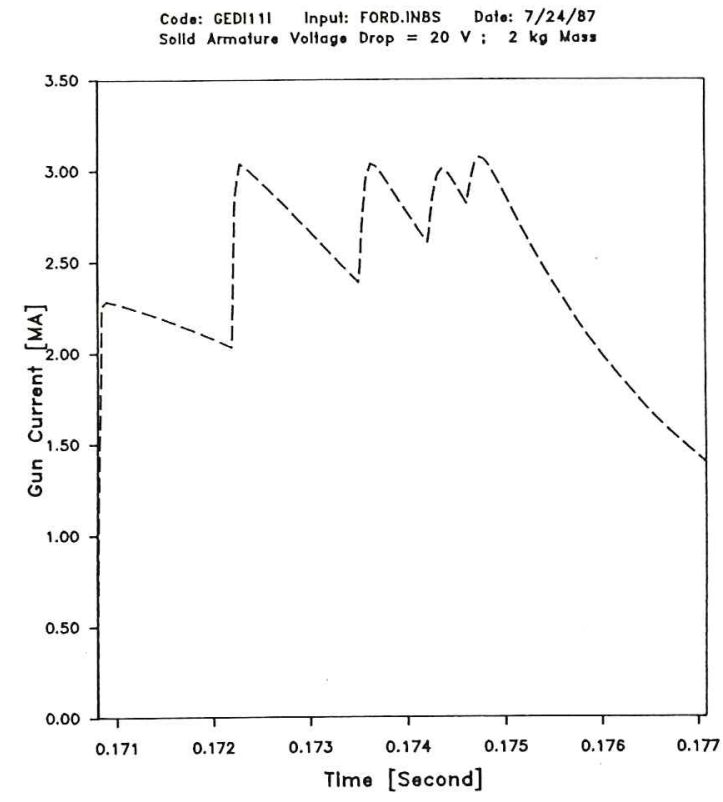

Figure 3. Tactica1 railgun computer mode1 (gun current vs. time)

\section{Railgun Design}

Early interface meetings on railgun design concentrated on geometry, operating pressure and railgun bore projectile interface issues. A simple yet informative analysis is presented in figure 7. For a given gun length and bore diameter the curves shown indicate the constant operating pressure that will produce $9 \mathrm{MJ}$ of muzzle energy. The constant pressure profiles are a1so identified with the current per unit rail height which is an EM yard stick for estimating therma1 loading and rail repulsive force. A large number of

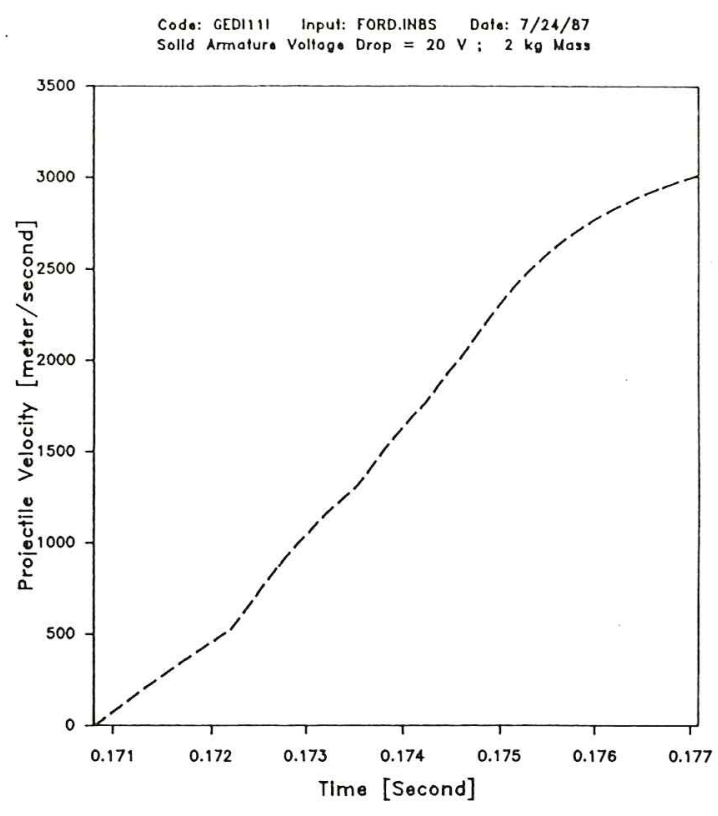

Figure 4. Tactical railgun computer mode1 (velocity vs. time)

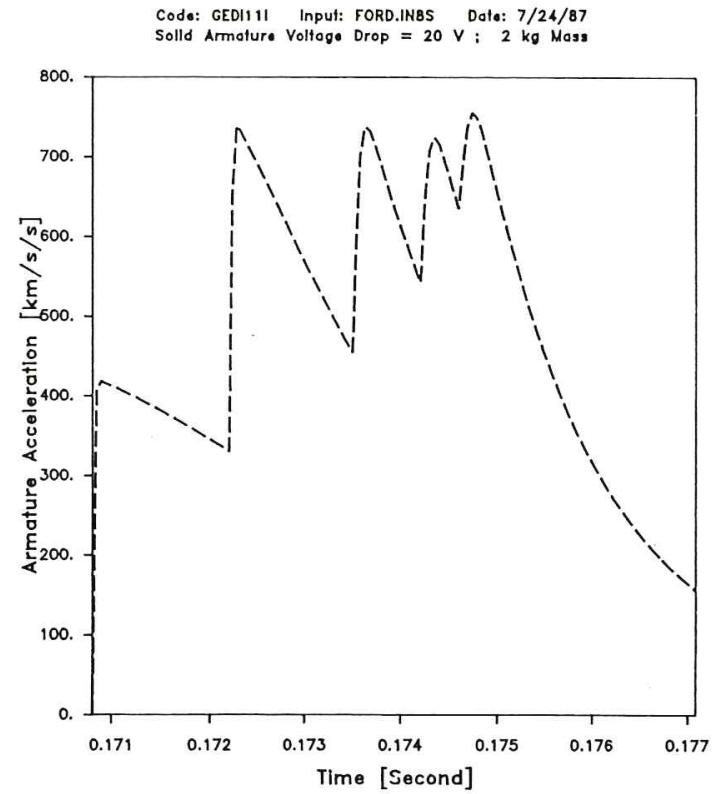

Figure 5. Tactical railgun computer model (armature acceleration vs. time) significant tests and the greatest body of operating experience in the EM community is centered at $30 \mathrm{MA} / \mathrm{m}$. At CEM-UT a five shot sequence had been performed in a $12.77 \mathrm{~m}$ bore gun at $40 \mathrm{MA} / \mathrm{m}$ with only minor bore reclamation required between shots. For these reasons bore sizes around $90 \mathrm{~mm}$ and a gun length of $10 \mathrm{~m}$ was considered for the $9 \mathrm{MJ}$ program. From a purely technical point of view a square bore gun was desired for a more uniform current distribution in the rails, but the vast majority of projectile and sabot design had been done for round bores. To draw on this large body of test data and experience the bore geometry was 


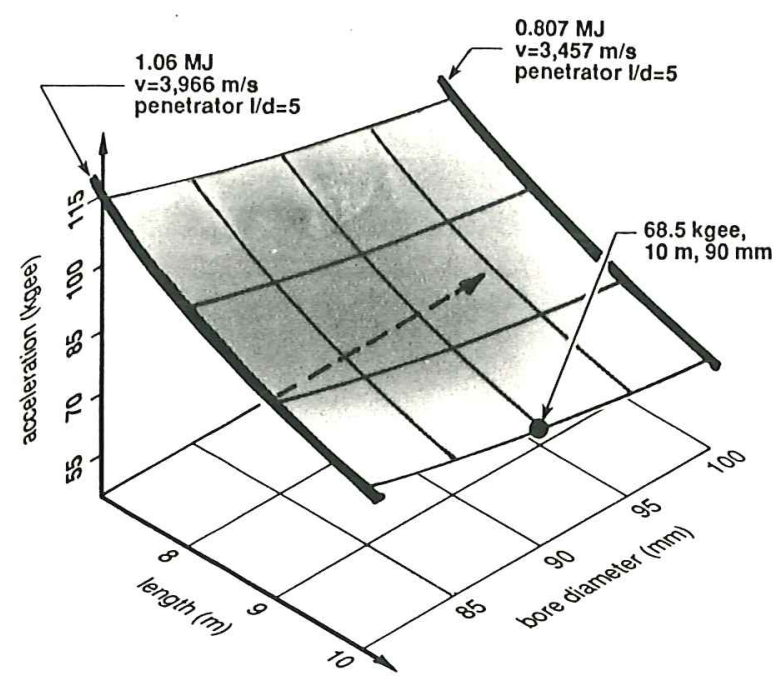

Figure 10. Acceleration vs. bore diameter and gun length

bore, and the ability to assemble and disassemble the rail and insulator components. The modern day smooth bore tank guns fire 9-MJ projectiles. The radial deflections of these guns under load will be used to establish a design goa1 for the EM gun. The EM gun for this program will achieve velocities much greater than conventional powder guns, but close to or just below the velocities of light gas guns. For this reason the bore and straightness tolerances will be adopted from light gas gun requirements. The light gas gun specifications are $0.001 \mathrm{in./in.} \mathrm{bore} \mathrm{runout}$ and straightnesses better than $0.002 \mathrm{in./ft.[3]}$

Enhanced structural stiffness 1imits the railgun deflection in response to an applied load. Large bore deflections can cause interference between gun and profectile, rebound damage as the gun relaxes after firing, sea1 failure and loss of sliding electrical contact. Preload and high modulous materials are used in conjunction to provide a stiff railgun. Figure 11 is a simple railgun cross section used to evaluate different structural materials. The rail insulator pair are supported in a tube and then the tube is preloaded with a steel support structure.

Tab1e 1 presents the results of a finite element analysis (FEA) which compares bore deflection for different test materials. It can be seen that ceramic emerges as an interesting railgun material. Ceramics have low tensile strength and must be biased into a favorable stress state[4]. The outer steel tube in figure 11 is assembled onto the ceramic with an interference fit to preload the rail insulator set and to hold the ceramic in a state of compression throughout the load cycle of firing the railgun.

The high modulus material surrounding the rail insulator package must undergo deflections large enough to close assembly clearances with rail insulator package, to close up gaps in the rail insu1ator axia1 seam introduced by machining tolerances, and a further deflection to provide an interference with the rail insulator assembly in order to establish a preload at the rail insulator boundary. Large stresses are developed in the outer tube which provides the force to deflect the internal diameter of the ceramic. For this reason high grade steels are selected for this duty. The steel must be sized for
Table 1. Comparison of structural support materials ( $85 \mathrm{~mm}$ bore - 50,000 psi loading)

\begin{tabular}{|c|c|}
\hline 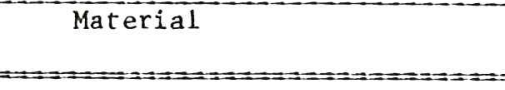 & $\begin{array}{l}\text { Rail Deflection } \\
\left(\text { in. } \times 10^{3}\right) \\
\end{array}$ \\
\hline Ceramic $(E=30 \mathrm{E} 6)$ & 8 \\
\hline $\begin{array}{l}\text { Isotropic material } \\
\quad(\mathrm{E}=15 \mathrm{E} 6)\end{array}$ & 13 \\
\hline $\begin{array}{l}\text { Carbon epoxy } \\
\quad \text { (vertical fibers) }\end{array}$ & 18 \\
\hline $\begin{array}{l}\text { Carbon epoxy } \\
\text { (radial fiber approximately) }\end{array}$ & 28 \\
\hline Carbon epoxy (hoop wrap) & 31 \\
\hline G10 & 37 \\
\hline EGlass (vertical fibers) & 43 \\
\hline EG1ass (hoop wrap) & 56 \\
\hline
\end{tabular}

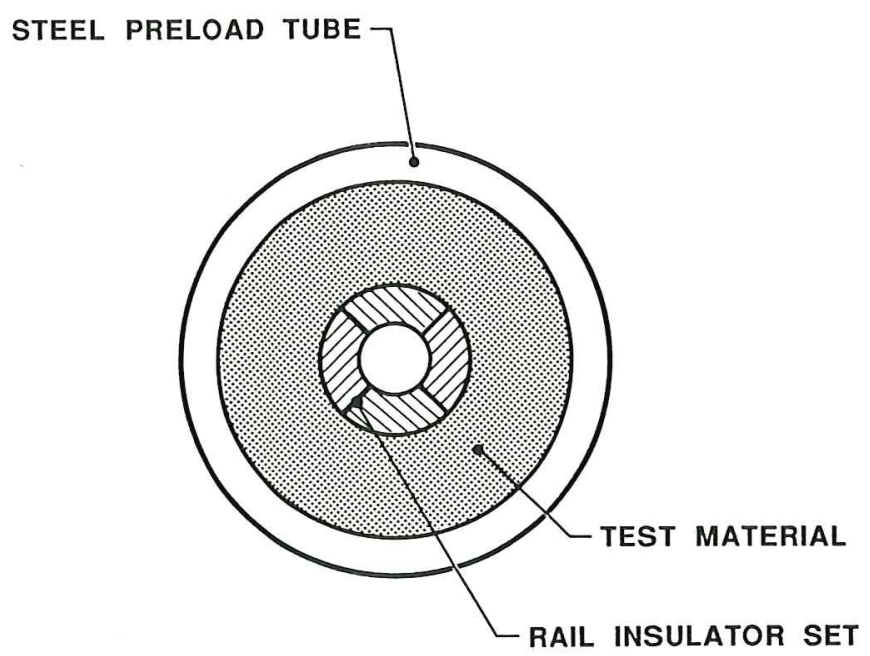

Figure 11. Railgun cross section

the proper structural properties while paying attention to the interaction between the pulsed fields created by the rails and the eddy currents generated in the steel she11. As the conducting shell is brought closer to the back of the rail the inductance gradient along the rails is degraded and therefore so is the developed EM force. A test set up to measure the high frequency inductance gradient is shown in figure 12. Mock components were built in the configuration shown in figure 13 and the test results with and without the steel tube are shown in figure 14. The introduction of the steel tube at 1.5 bore dimensions behind the rail results in a $12 \%$ reduction in driving force.

In the final design electromagnetic performance was traded for cost and weight and the steel support tube was placed at 1.5 bore dimensions behind the rails. Figure 15 identifies gun dimensions and presents cost and weight data for tube and rails separation of $1.0,1.5$, and 2.0 bore dimensions. Shown in 


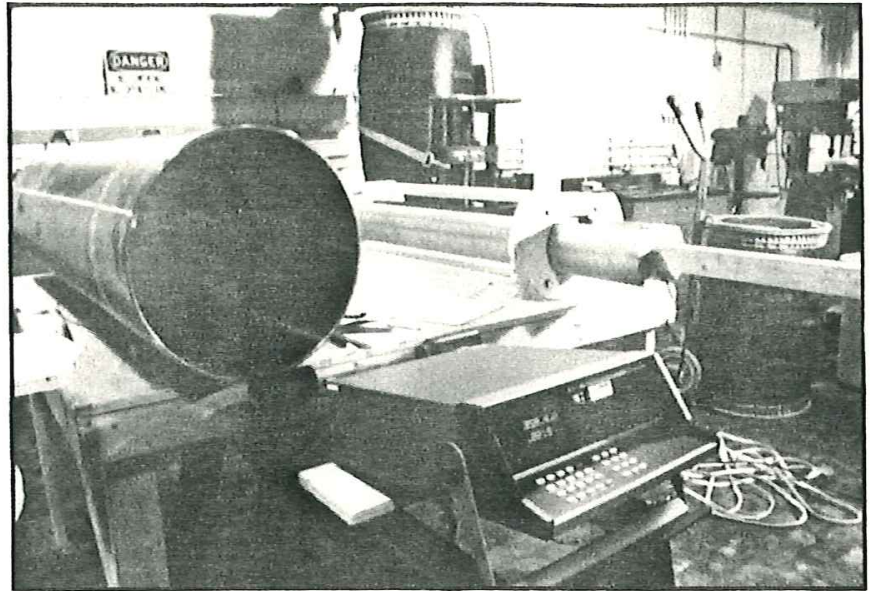

Figure 12. Railgun magnetic measurement components

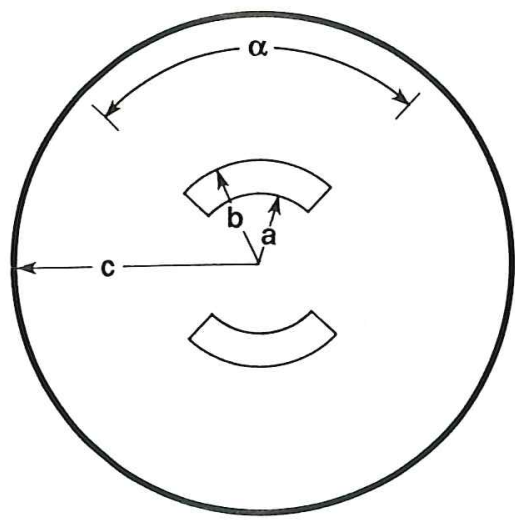

$$
\begin{aligned}
a= & 1.75 \mathrm{in} . \\
b= & 3.25 \mathrm{in} . \\
c= & 8.5 \mathrm{in} . \\
\alpha= & 90^{\circ} \\
L^{\prime}= & 0.36 \mu \mathrm{H} / \mathrm{m} \\
& \text { at } 100 \mathrm{kHz}
\end{aligned}
$$

Figure 13. Summary of full scale inductance measurements

figure 16 is a half section of one rail. The rail has been divided into filaments to analyze its thermal response to the current waveform shown in figure 3. [5] The criterion for an acceptable rail cross section was that the rail hot spot should not exceed one half the melting temperature of the rail material.

The final goal to rapidly change rails and insulators was realized after thoroughly reviewing numerous approaches. Difficulties associated with the manufacture of very large high strength ceramic parts requires that a support tube the length of the gun be made up of individual disks. At initial assembly, the alumina disks will be installed with a 0.002 in. radial clearance press fit into a two piece steel tube consisting of a heavy structural tube with a liner, figure 17. High pressure hydraulic seals are installed between the outer pressure vessel and inner compression sleeve at each end of the vessel and are held in place with end caps. The gap between tubes is

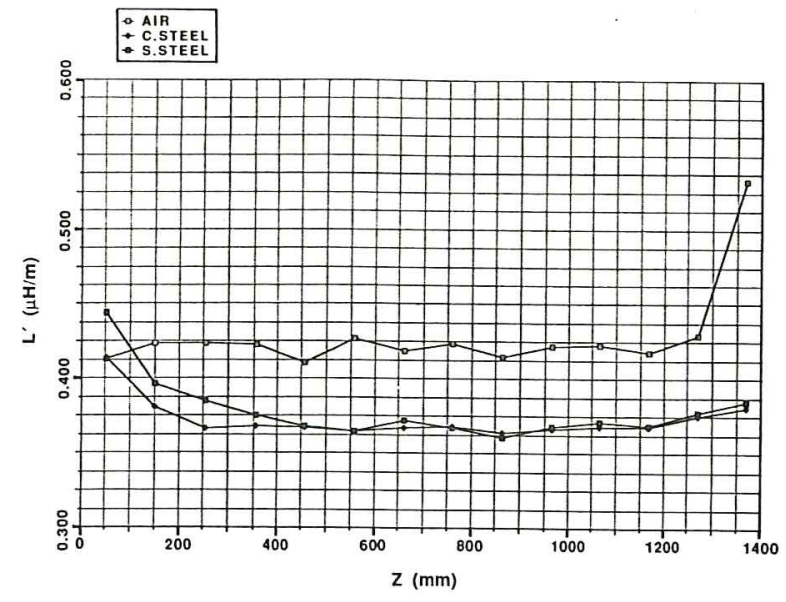

\begin{tabular}{|c|c|c|c|c|}
\hline Case: & $I$ & II & III & Units \\
\hline $\begin{array}{c}\mathrm{T} / \mathrm{D} \\
\mathrm{B} / \mathrm{A} \\
\mathrm{B} \\
\mathrm{C} \\
\mathrm{C}-\mathrm{B}\end{array}$ & $\begin{array}{c}1.0 \\
2.0 \\
6.75 \\
10.25 \\
3.5\end{array}$ & $\begin{array}{c}1.5 \\
2.5 \\
8.5 \\
11.5 \\
3.0\end{array}$ & $\begin{array}{c}2.0 \\
3.0 \\
10.25 \\
12.75 \\
2.5\end{array}$ & in \\
\hline $\begin{array}{l}\text { Weight } \\
\text { Cost }\end{array}$ & $\begin{array}{l}26.9 \\
126\end{array}$ & $\begin{array}{l}31.4 \\
181\end{array}$ & $\begin{array}{l}35.9 \\
326\end{array}$ & $\begin{array}{l}k \text { Ib } \\
k \$\end{array}$ \\
\hline
\end{tabular}

Figure 14. High frequency inductance measurements on tactical railgun mock up
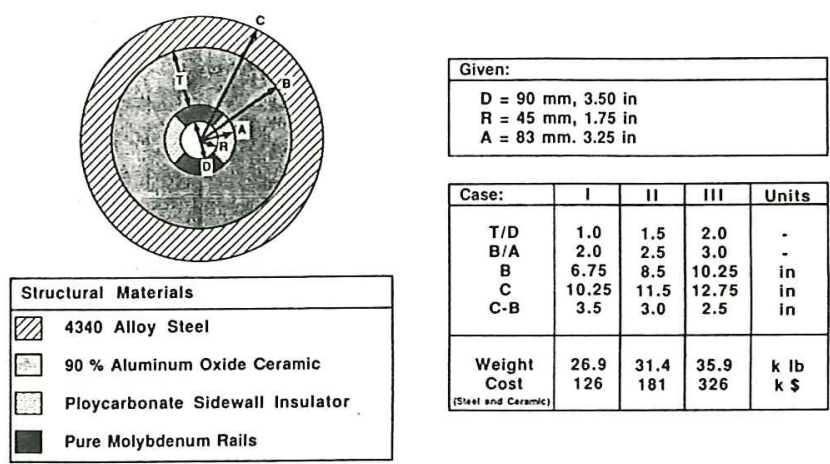

Figure 15. Geometric conventions

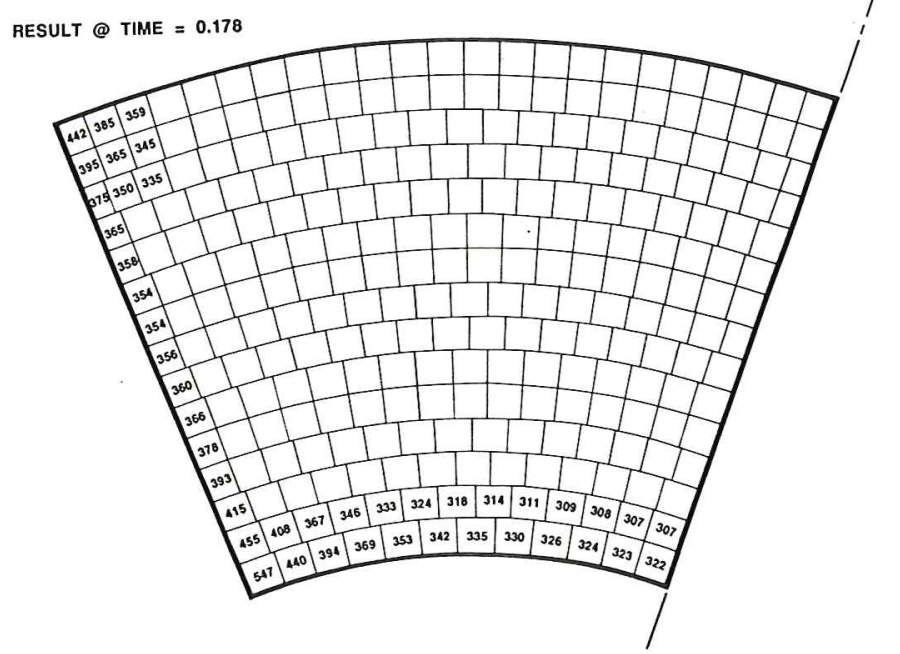

Figure 16. Temperature distribution (in degrees kelvin) in a half section copper rail. This cross section is at the breech of the gun and has been subjected to the current profile in figure 3 . 


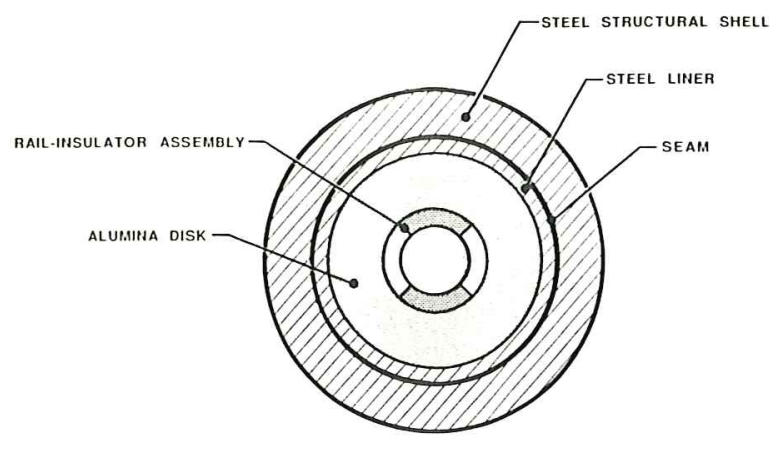

Figure 17. Hydraulically clamped railgun cross section

taken to an intermediate pressure to 1ock the ceramic disks in place. The inner diameter of the ceramic is then honed to produce a precision bore and the rail insulator package is pulled into this bore with a 0.003 in. radial clearance. Next the hydraulic medium will be taken to $30 \mathrm{ksi}$ to bias the ceramic into compression and to preload the rail insulator assemb1y. A drawing of the assembly is given in figure 18. The hydraulic pressure is maintained continuously until the rails are removed. Releasing the hydraulic pressure will enable removal of the rails[6].

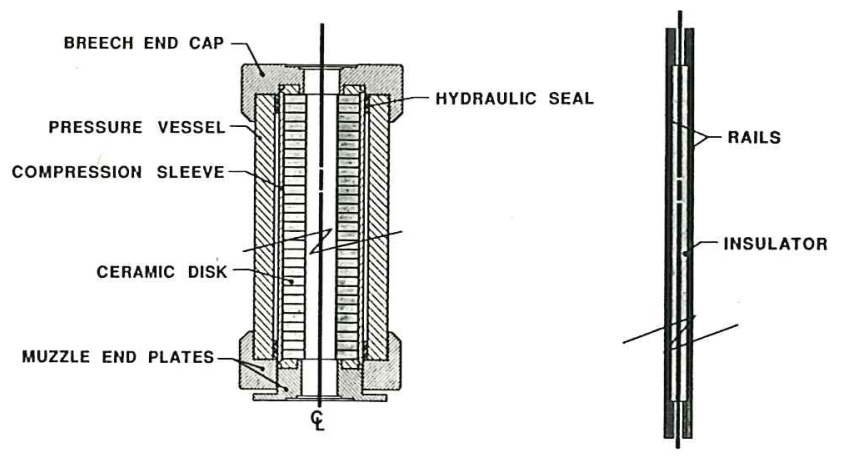

Figure 18. Hydraulically prestressed railgun structure

A two dimensiona1 dynamic finite element analysis has been done for the structure shown in figure 17. A dynamic response factor of 1.08 has been determined for the railgun. Table 2 compares the static response of a conventiona $120 \mathrm{~mm}$ smooth bore gun to a $90 \mathrm{~mm}$ railgun with both copper and molybdenum rails. It can be seen that analytically the railgun structures are approaching the behavior of monolithic steel gun tubes.

\section{Bore Preparation and Gauging}

A honing machine is required in the railgun facility to prepare the ceramic stack for rail insertion, to establish initial bore tolerances, and to refurbish bores between shots[8]. The honing machine is shown in figure 1 above the breech of the gun. Because the hone and gun bore remain in alignment rapid set up and turn around are realized. The hone will both reciprocate and rotate. Pure reciprocation is required for square bores whereas a partial rotation per long stroke might be required for polishing round bores.
Table 2. Bore deflection comparison

\begin{tabular}{|c|c|c|c|}
\hline \multirow[b]{3}{*}{ RAILGUN BORE } & & $\begin{array}{l}\text { Hydraulically } \\
\text { preloaded } \\
\text { ceramic }\end{array}$ & $\begin{array}{l}\text { Hydraulically } \\
\text { preloaded } \\
\text { ceramic }\end{array}$ \\
\hline & Conventional & EM gun & EM gun \\
\hline & $\begin{array}{ll}\begin{array}{l}\text { Smooth } \\
\text { powder Gore } \\
\text { [7] }\end{array} & \\
\end{array}$ & $\begin{array}{l}\text { Copper } \\
\text { rails }\end{array}$ & $\begin{array}{l}\text { Molybdenum } \\
\text { rails }\end{array}$ \\
\hline $\begin{array}{l}\text { Deflection } \\
\mathrm{mm},(\mathrm{mi} 1 \mathrm{~s})\end{array}$ & $0.228 \quad(0.009)$ & $0.284(0.011)$ & $0.204(0.008)$ \\
\hline $\begin{array}{l}\text { Bore diameter } \\
\mathrm{mm}\end{array}$ & 120 & 90 & 90 \\
\hline $\begin{array}{l}\text { Peak pressure } \\
\mathrm{MPa}, \text { (kBi) }\end{array}$ & $(69.8)$ & $373(54.1)$ & $373(54.1)$ \\
\hline
\end{tabular}

The honing heads are equipped with 1ong lasting diamond abrasive elements which are of importance when honing such candidate bore materials as molybdenum rails and ceramic sidewalls.

It is important to measure bore wear on a per shot basis and to record the effect of bore diametral and straightness tolerances on hypervelocity projectile performance. Both of these measurements are made with a common instrument. A round mandre1 locks in the bore with inflatable bladders. Mounted to the mandrel are 12 diametrically opposed cantilever arms instrumented with strain gauges. The gauges are zeroed and calibrated in an external fixture before insertion into precision honed dummy tubes. Once the calibration is verified the gauge is inserted in the railgun bore and diameter data from muzzle to breech is stored in a microcomputer via a data link. The bore diameter data is accurate to within 0.0005 in. The bore straightness is measured by shining a laser (hard mounted as a global reference) on a focal plane array mounted on the end of the bore gauging mandrel. At each measuring position the motion from the global reference beam is measured to within $0.001 \mathrm{in./ft}$ and stored in computer memory. The data may then be plotted via a graphics interface. This information is particularly interesting to projectile designers for predicting balloting wear and lateral forces applied to fragile nose tips during projectile acceleration.

\section{Projectile Test Range}

This task of the program was subcontracted to the BDM corporation[9]. BDM's responsibilities were to design and fabricate a test range suitable for investigating the operational performance of a $9 \mathrm{MJ}$ single shot EM gun and projectiles fired from that gun. In addition BDM was to provide assistance in interfacing with the areas of Hypervelocity Projectile Technology, Mission Parameters, and Fire Control programs.

The design goal for the test range was to provide a well instrumented flight range that could be safely operated in a populated area. The requirement for the range was that the tunnel wall must be capab1e of fully stopping the penetrator and sabot, including containing any spall generated by the impact. Impact was assumed oblique to the wa11. The original concept for the range was a horizontal tunnel with a $30-\mathrm{m}$ flight range. Ear1y penetration analyses by the Task 
D1 projectile designers were indicating that $2 \mathrm{ft}$ of steel would be required to stop the penetrator. Budgetary estimates on a steel tunne1 $30 \mathrm{~m}$ 1ong with 2 ft thick steel walls precluded this design as being an option. Such a range would not have much growth potential if the program was successful and testing of higher energy projectiles was required. The answer to the safety concerns and growth potential was to construct a vertical range with a1l below ground operations.

The locations of the instrumentation floors are shown in figure 1. The first instrumentation floor is located $4 \mathrm{ft}$ below the gun muzzle in order to allow easy access to the muzzle for gun maintenance and muzzle exit diagnostics. Four more instrumentation floors are located $10 \mathrm{ft}$ intervals below the muzzle floor, followed by three floors at $20 \mathrm{ft}$ intervals. The last floor is solid and constitutes the roof of the enclosed target chamber. This floor layout allows extensive access for optical diagnostics in the first $50 \mathrm{ft}$ from the muzzle, which is considered a critical area for first yaw maximum and sabot separation.

The layout of the permanent structures associated with each floor (elevator, access doors, ladders, utility ducts, and so forth) must allow every floor to support any of several possible configurations of instrumentation. The major instrumentation setups are shadowgraph, flash X-ray, and high speed cameras.

The range is designed for maximum ease of target mounting and access, which is provided by a movable target support structure and a set of doors allowing crane access to the target.

The target is supported by a structure which slides on greased skids along a pair of rails across the target chamber. The target can thus be lowered through the central craneway, installed in the support structure, and slid into place under the flight tube. Movement of the support structure is achieved with an electric winch, which is estimated to be of approximately 1,200 1b capacity. The target support structure will incorporate shock mountings to minimize the impulsive loads on the support rails.

The support structure is sized to permit use of a monolithic RHA target $2 \mathrm{ft} \times 2 \mathrm{ft} \times 4 \mathrm{ft}$, which will weigh about 7,800 1b; more complex or inclined targets will be supported in a cage affixed to the support structure. Since it is not clearly established at this time how or by whom targets will be supplied, BDM intends to define an interface standard for the target support structure to which outside contractors may design their target mountings.

The optical access to the flight tube needed for the muzzle exit and in-flight diagnostics is supplied by windows installed in sets of four to provide pairs of orthogonal views. The windows at the muzzle are 2 $\mathrm{ft}$ high and $1 \mathrm{ft}$ wide, and are currently designed to be Lexan" with a Pyrex" facing on the inside to reduce the effect of muzzle arcs; a11 other windows are a11-Lexan" structures $3 \mathrm{ft} 6 \mathrm{in}$. high and $1 \mathrm{ft}$ wide. The window thickness will be sufficient to resist the air shock of normal projectile flight. The flange and retaining-ring design of the window support allows great flexibility, so much thicker panes can later be installed if they prove necessary.

The instrumentation available at this time is shown in table 3. It is the belief of the Center for E1ectromechanics and BDM corporation that this unique range design is safe, operationally functional, and will fully support the testing of hypervelocity projectiles.
Table 3. Current instruments

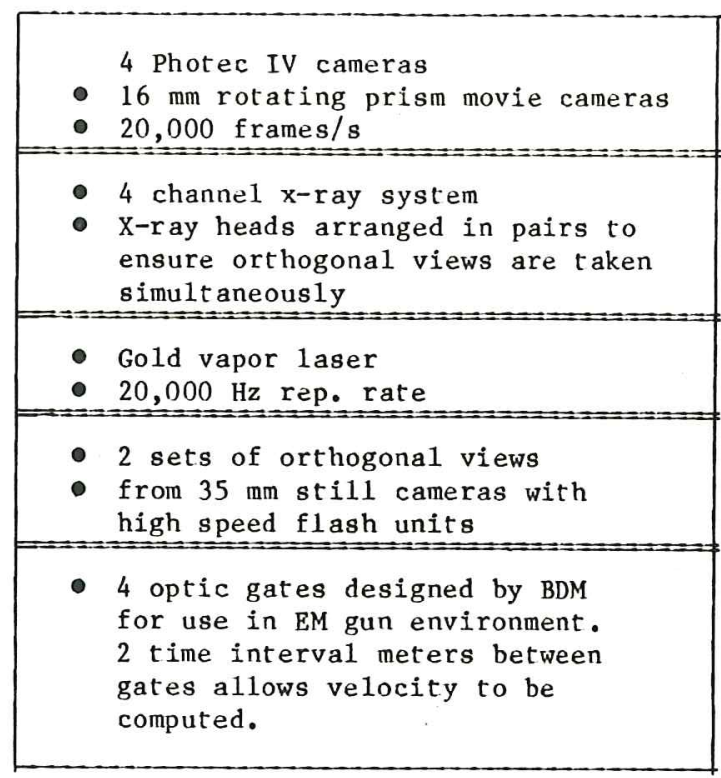

\section{Testing}

A $45 \mathrm{~mm}$ bore diameter $3 \mathrm{~m}$ 1ong hydraulica1ly preloaded railgun has been fabricated and test shots are being conducted in the Task $B$ range. The impetus of the testing has been to improve the performances of solid armatures. During the design and construction of the range and the railguns a solid armature test program was conducted in a $12.7 \mathrm{~mm}$ square bore $1 \mathrm{~m}$ long railgun. During that testing monolithic aluminum armatures in the fishbone geometry showed favorable performance[10] (fig. 19). From this design the cylindrical aluminum fishbone armature evolved, ( $f$ ig. 20). Table 4 is a summary of the experiments conducted in the one half scale gun. It can be seen that the muzzle energy has steadily increased and muzzle velocity in a small number of test shots is equal to the muzzle velocity of a conventional $120 \mathrm{~mm}$ powder driven gun. Future testing will concentrate on increasing the velocity, designing a mechanical joint between the rear contact and the body of the armature (this will simulate the solid armature to sabot interface), and to iterate on sliding contact design to minimize bore damage.

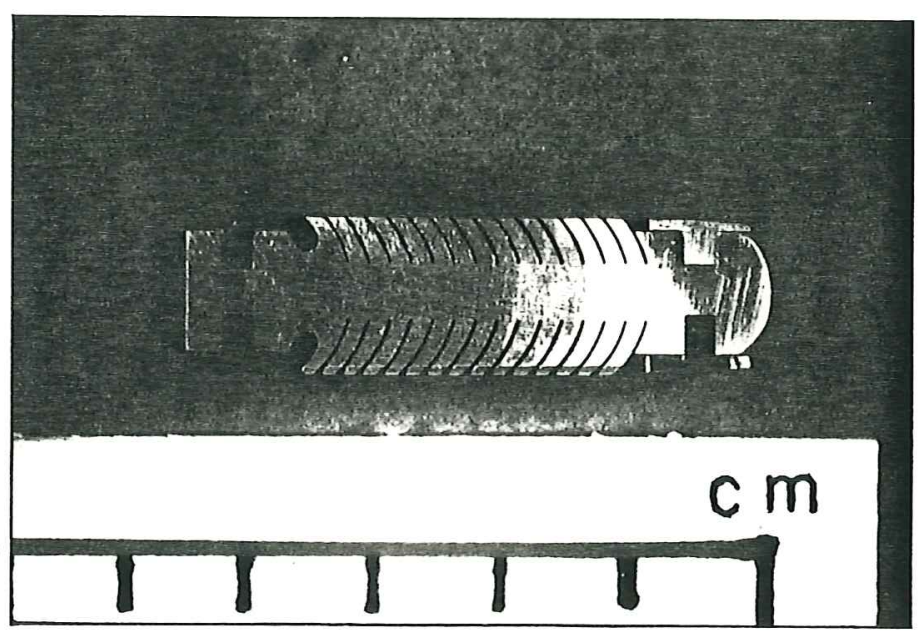

Figure 19. Fishbone armature 
Table 4. Shot summary--45 mm hydraulic railgun

\begin{tabular}{|c|c|c|c|c|c|c|c|c|c|}
\hline $\begin{array}{l}\text { Shot } \\
\text { No. }\end{array}$ & $\begin{array}{l}\text { Shot } \\
\text { Date }\end{array}$ & $\begin{array}{l}\text { Muzzle } \\
\text { Velocity } \\
(\mathrm{m} / \mathrm{s})\end{array}$ & $\begin{array}{l}\text { Projectile } \\
\text { Mass } \\
\text { (g) }\end{array}$ & $\begin{array}{l}\text { Projectile } \\
\text { Type }\end{array}$ & $\begin{array}{l}\text { Peak } \\
\text { Current } \\
\text { (MA) }\end{array}$ & $\begin{array}{l}\text { Exit } \\
\text { Current } \\
\text { (MA) }\end{array}$ & $\begin{array}{l}\text { Projectile } \\
\text { Exit Time } \\
(\mathrm{ms})\end{array}$ & $\begin{array}{l}\text { Projectile } \\
\text { Velocity and } \\
\text { Integrity } \\
\text { Confirmation }\end{array}$ & Comments \\
\hline 1 & $9 / 10 / 87$ & 660 & 409 & $\begin{array}{l}\text { cylindrical } \\
\text { aluminum } \\
\text { fishbone }\end{array}$ & 0.98 & $\mathrm{NA}$ & 6 & Yes & $\begin{array}{l}\text { Bore undamaged. Profectile } \\
\text { glanced off flight tube near } \\
\text { target chamber. Breech and } \\
\text { muzzle volts not recorded } \\
\text { (oscilloscope falled to } \\
\text { trigger). Failure of tem- } \\
\text { porary bus connections. }\end{array}$ \\
\hline 2 & $9 / 28 / 87$ & 1,200 & 360 & $\begin{array}{l}\text { cylindrica1 } \\
\text { aluminum } \\
\text { fishbone }\end{array}$ & $\overline{0.98}$ & 0.57 & 4 & $\begin{array}{l}\text { No (1ate } \\
\text { flash) }\end{array}$ & $\begin{array}{l}\text { Bore undamaged. All data } \\
\text { recorded. Low muzzle volts. } \\
\text { Repaired bus connection suc- } \\
\text { cessful. Projectlle struck } \\
\text { flight tube. }\end{array}$ \\
\hline 3 & $10 / 2 / 87$ & 1,200 & 360 & $\begin{array}{l}\text { cylindrical } \\
\text { aluminum } \\
\text { fishbone }\end{array}$ & 1.13 & 0.40 & $\overline{3.6}$ & $\begin{array}{l}\text { Yes (flash } \\
\text { timing } \\
\text { corrected) }\end{array}$ & $\begin{array}{l}\text { Two shots in one week. Bore } \\
\text { undamaged. } 0.5 \text { in. steel } \\
\text { plate easily penetrated. } \\
\text { Low muzzle voits. One } \\
\text { breech crowbar shorted } \\
\text { early, diverting current } \\
\text { from the gun. }\end{array}$ \\
\hline 4 & $10 / 22 / 87$ & $\mathrm{NA}$ & 1,445 & $\begin{array}{l}\text { cylindrical } \\
\text { aluminum } \\
\text { fishbone \& } \\
\text { Kaman } \\
\text { Sciences' } \\
\text { penetrator }\end{array}$ & 1.30 & $\mathrm{NA}$ & NA & $\begin{array}{l}\text { Photos show } \\
\text { projectile } \\
\text { broke up in } \\
\text { gun }\end{array}$ & $\begin{array}{l}\text { Photographs indicate } \\
\text { armature and projectile } \\
\text { broke up in bore. Rails and } \\
\text { insulators severely damaged. }\end{array}$ \\
\hline 5 & $12 / 14 / 87$ & 1,550 & 240.20 & $\begin{array}{l}\text { cylindrical } \\
\text { aluminum } \\
\text { fishbone }\end{array}$ & 1.045 & 0.625 & 3.0 & Yes & $\begin{array}{l}\text { Muzzle volts indicate tran- } \\
\text { sition } 1.3 \text { ms into shot. } \\
0.027 \text { in. honed to reclaim } \\
\text { bore. Gun resistance before } \\
\text { shot } 3 \mathrm{M} \Omega \text { after shot } 500 \mathrm{k} \Omega \text {. }\end{array}$ \\
\hline 6 & $12 / 18 / 87$ & 1,660 & 253.40 & $\begin{array}{l}\text { cylindrical } \\
\text { aluminum } \\
\text { fishbone }\end{array}$ & 1.09 & 0.600 & 3.1 & $\begin{array}{l}\text { No } \\
\text { (no flash, } \\
\text { f1lm in } \\
\text { cameras } \\
\text { broke) }\end{array}$ & $\begin{array}{l}\text { Muzzle volts indicate tran- } \\
\text { sition at } 1.1 \text { ms into shot. } \\
0.028 \text { in. honed to reclaim } \\
\text { bore. Gun resistance before } \\
\text { shot } 0.5 \mathrm{M} \Omega \text { after shot } \\
0.5 \mathrm{M} \Omega \text {. }\end{array}$ \\
\hline 7 & $1 / 19 / 88$ & 1,575 & 253.20 & $\begin{array}{l}\text { cylindrical } \\
\text { aluminum } \\
\text { fishbone }\end{array}$ & 1.16 & 0.450 & 3.0 & Yes & $\begin{array}{l}\text { Muzzle volts indicate tran- } \\
\text { sition at } 1.2 \mathrm{~ms} \text { into shot. } \\
0.0174 \text { in. honed to reclaim } \\
\text { bore. Gun resistance before } \\
\text { shot } 300 \mathrm{k} \Omega \text { after shot } 125 \\
\mathrm{k} \Omega \text {. Breech buswork } \\
\text { flashover at } 1.3 \mathrm{~ms} \text { degraded } \\
\text { performance. }\end{array}$ \\
\hline
\end{tabular}

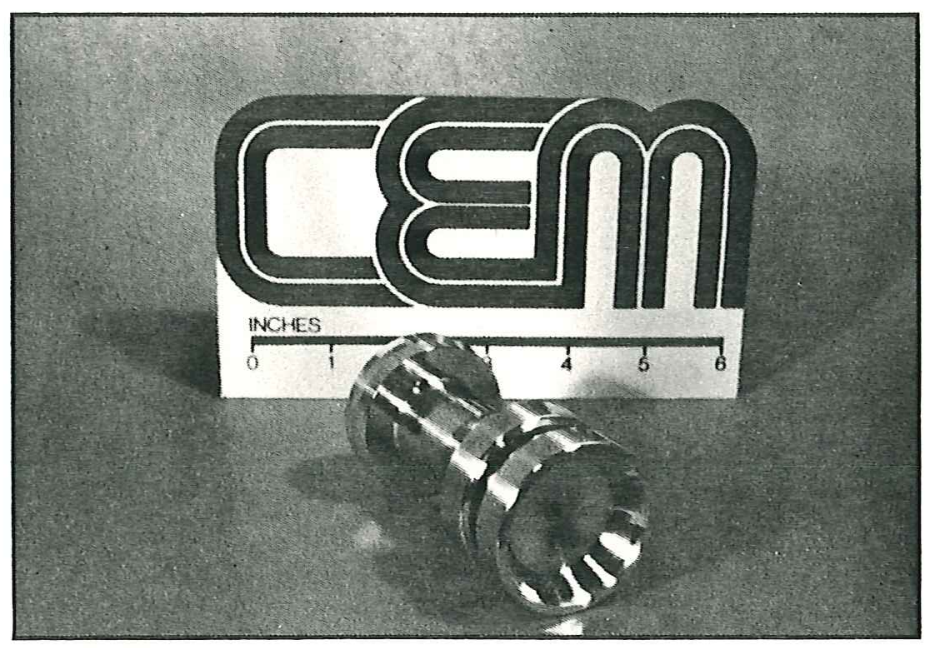

Figure 20. Cy1indrica1 fishbone armature

Al1 parts for the $90 \mathrm{~mm}$ bore 5 and $10 \mathrm{~m}$ long railguns have been fabricated. The $5 \mathrm{~m}$ gun will be assembled and ready for testing in the near future.

\section{Conc1usions}

The majority of the mass of the $10 \mathrm{~m}$ Task $B$ single shot lab gun is attributable to the outer pressure vessel. The pressure vessel is required for this design so that the rails and insulators may be changed in a rapid manner. Figure 21 presents a weight comparison between a conventional tank gun, the $1 \mathrm{ab}$ based single shot gun, and a conceptual combat rated gun. FEA analysis has been used to identify geometries and materials that produce a structure as stiff as the $1 \mathrm{ab}$ based gun and weighing less than the conventional tank gun. This design like the conventional gun would be operated for its shot life and then decommissioned. The challenge is to use the Task B gun to identify rail and insulator materials which equa1 or surpass the shot life demonstrated by the conventional gun.

Ear1y in the design evolution the projectile designers recognized the Task $B$ gun as having characteristics of a Mann Barrel. A Mann Barrel is an exceptiona11y stiff gun mounted to minimize recoil moments. These barrels are used to decouple projectile behavior from bore motion. The hydraulically preloaded ceramic gun hanging straight down from a single point mount fulfills both conditions and should be an excellent test device for development hypervelocity projectiles.

Particular attention has been paid to railgun projectile interface issues in this program. Development of two and three dimensional FEA structural codes have allowed prediction of bore response to loading conditions. This information has been passed on to pro- 


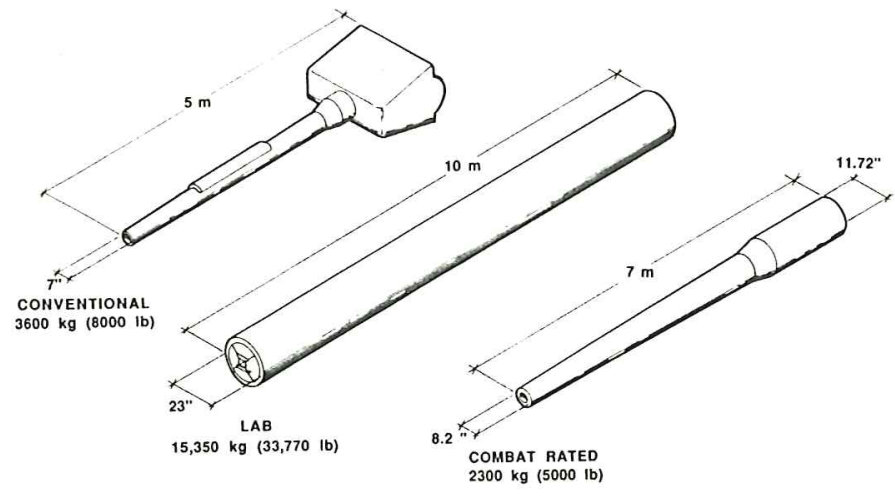

Figure 21. Gun comparison

jectile designers to be input to their analytical models. A great effort has been applied to bore preparation and measuring system to insure diametral and straightness tolerances. Accurate system simulations have been developed to provide the projectile designers with acceleration and jerk data throughout the shot. A complete instrumentation suite is provided to measure demuzzling effects, sabot separation and projectile yaw behavior. Test programs are currently underway to develop solid armature designs for high sliding speeds and to design a reliable armature to projectile mechanical coupling.

A1so of great importance to this research program is the safe operation of the hypervelocity gun range. Al1 below ground operation allows for safe operation within the city of Austin.

\section{Acknowledgements}

This research was funded by Defense Advanced Research Projects Agency and U. S. Army Armament Research, Development, and Engineering Center.

\section{References}

D. R. Peterson, J. H. Price, W. F. Weldon, R. C. Zowarka, W. C. G. Fulsher, J. H. Hahne, "Design and Operation of a High Energy Railgun Fadility," paper presented at the Fourth Symposium on Electromagnetis Launch Technology, Austin, TX, Apri1 12-14, 1988.

[2] A. Y. Wu, M. D. Driga, H. H. Woodson, and R. C. Zowarka, "Simulation and Predicted Performance of the Balcones GEDI Experiment," IEEE Transactions on Magnetiss, Vo1. MAG-22, No. 6, November 1986, pp 1817-1822.

[3] H. F. Swift, D. E. Strange, and M. Nagy, "The Kinematic Bore Geometry Gauge," 37th Meeting of the Aeroballistis Range Assosiation, Quebec, Canada, 1986.
E. P. Fahrenthold, D. R. Peterson, J. H. Price, and A. Y. Wu, "Stress Analysis for Design of Electromagnetic Launchers," Journal of Vibration, Acoustics, Stress, and Reliability in Design.
[5]

A. Y. Wu, K. S. Sun, "Formulation and Implementation of the Current Filament Method for the Analysis of Current Diffusion and Heating in Condustors in Railguns and Homopolar Generators," paper presented at the Fourth Symposium on Electromagnetic Launch Technology, Austin, TX, Apri1 12-14, 1988.

J. H. Prise, E. P. Fahrenthold, D. R. Peterson, W. F. Weldon, R. C. Zowarka, W. C. G. Fulcher, and M. W. Ingram, "Design and Testing of Large Bore, U1trastiff Railguns," paper presented at the Fourth Symposium on Electromagnetic Launch Technology, Austin, TX, Apri1 12-14, 1988 .

[7] Persome1 communication with Bob Becker, $S \& D$ Dyuamics, Hunnington, Long Island, NY.

[8] D. R. Peterson, M. W. Harville, W. F. We1don, R. C. Zowarka, and J. H. Price (Center for Electromechanios, The University of Texas at Austin), and T. Connor, (General Hone), "Produoing and Gaging Presision Railgun Bores," paper presented at the Fourth Symposium on E1estromagnetic Launoh Teshnology, Austin, TX, Apri1 12-14, 1988.

[9] B. Firey, J. Lynch, and F. Mayer, "Operation of a Ballistic Range for 9 MJ Tastical Railgun Testing," paper presented at the Fourth Symposium on Elestromagnetic Launch Technology, Austin, TX, Apri1 12-14, 1988.

[10] J. H. Prise, W. C. G. Fulcher, M. W. Ingram, D. E. Perkins, D. R. Peterson, and J. A. Pappas, "Results of Monolithio Solid Armature Tests in a Railgun," paper presented at the 1987 International Current Collector Conference, Austin, TX, November 16-17, 1987. 